\title{
Case of an extra-large biliary intraductal papillary neoplasia
}

\author{
Raquel Madaleno, António Pedro Pissarra, Filipe Caseiro-Alves
}

Radiology, Centro Hospitalar e Universitario de Coimbra EPE, Coimbra, Portugal

Correspondence to Dr Raquel Madaleno; raquelrdmadaleno@gmail.com

Accepted 26 October 2019

\section{DESCRIPTION}

Intraductal papillary neoplasia (IPNB) is a biliary epithelial premalignant tumour with a predominant papillary intraductal growth. ${ }^{1}$ IPNBs arise from peribiliary glands, which are rich in biliary tree progenitor cells with potential to differentiate into hepatocytes, cholangiocytes and pancreatic islets. ${ }^{2}$ In 2010 , it was added to the WHO classification, encompassing from low-grade intraductal neoplasia to IPNB with invasive carcinoma (present in 40\%-80\% IPNBs) that represents intraductal growth-type cholangiocarcinoma. ${ }^{13}$

Nearly one-third of IPNB show histological and immunophenotypic similarities with pancreatic intraductal papillary mucinous neoplasm (IPMN), with production of mucin, while IPNBs without mucin hypersecretion resemble nonpapillary cholangiocarcinomas. $^{24}$

IPNBs are endemic in Far Eastern countries, usually between fourth and sixth decades of life, associated with hepatolithiasis and clonorchiasis. $^{3}$

We present a case of a Caucasian 65-year-old woman, with prior cholecystectomy, presented at the emergency department with intermittent jaundice, coluria, pruritus and abdominal pain. Blood investigations revealed raised hepatic transaminases, gamma-glutamyl transferase

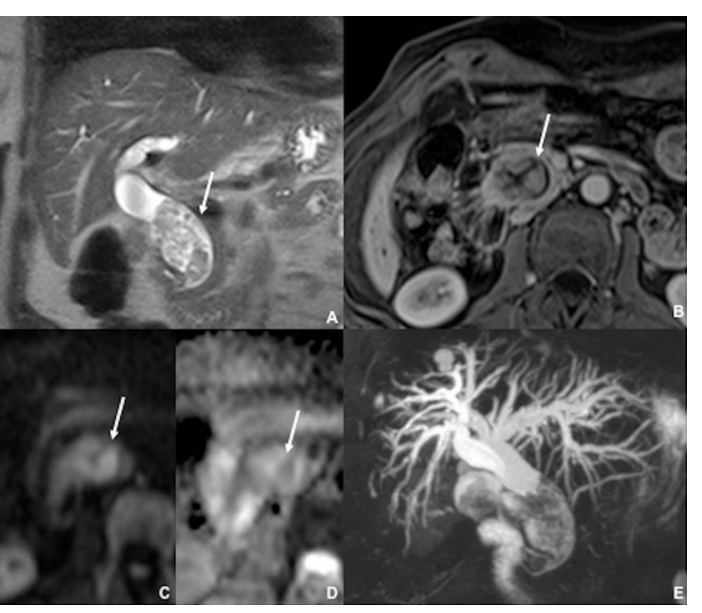

Figure 1 Coronal T2-weighted (A), axial contrastenhanced three-dimensional gradient echo image with fat suppression after contrast injection (B) and diffusionweighted imaging $(C)$ with apparent diffusion coefficient map (D) MR images show the intraductal papillary neoplasia (white arrows in A-D) as a large intraductal solid lesion, occupying the distal two-thirds of the CBD. MRCP (E) shows upstream dilatation of the biliary tract.
(GGT) and alkaline phosphatase (ALP) and normal tumour markers.

The patient underwent ultrasound examination which revealed a non-specific extrahepatic intraductal lesion, combined with dilatation of the proximal biliary tree. MR with magnetic resonance cholangiopancreatography (MRCP) depicted a large intraductal solid lesion, occupying the distal two-thirds of the common bile duct (CBD) (figure 1A-D), with upstream dilatation of the biliary tract (figure 1E), compatible with IPNB.

After surgical resection, histopathology examination revealed a high-grade IPNB, with a pancreaticobiliary phenotype with an invasive adenocarcinoma component.

IPNBs are usually sessile or polypoid lesion and can have multifocal superficial spreading masses along the mucosal surface, in both intrahepatic and extrahepatic bile ducts, known as papillomatosis. These multiple lesions may detach spontaneously, mimicking biliary lithiasis. ${ }^{5}$

On imaging, IPNBs can have five patterns: diffuse duct ectasia with a grossly visible papillary mass (type 1); diffuse duct dilatation without a visible mass (type 2); localised ductal ectasia with an intraluminal polypoid mass (type 3 ); intraductal cast-like lesions (type 4) and mild ductal dilation proximal to a focal stricture-like lesion (type 5). ${ }^{36}$

Only complete surgical resection allows a curative treatment. IPNBs have a better prognosis when compared with conventional cholangiocarcinoma,

\section{Patient's perspective}

I am pleased that my case helps the scientific community and so can help other patients.

\section{Learning points}

Intraductal papillary neoplasia (IPNB) is an uncommon form of epithelial biliary papilomatosis with a variable degree of malignancy that may be clinically present by jaundice and coluria.

- Imaging of IPNBs can range from a localised or diffuse biliary dilatation, with or without visible intraluminal mass to a focal stricture evoking cholangiocarcinoma.

- The only curative treatment is complete surgical resection. 
with 5 -year survival rates between $60 \%$ and $82 \%$ in patients undergoing R0 resection. ${ }^{7}$

Contributors RM interpreted the MRI scan and together with APP wrote the article. FC-A was involved in patient management and reviewed the article.

Funding The authors have not declared a specific grant for this research from any funding agency in the public, commercial or not-for-profit sectors.

Competing interests None declared.

Patient consent for publication Obtained.

Provenance and peer review Not commissioned; externally peer reviewed.

\section{REFERENCES}

1 Ohtsuka M, Shimizu H, Kato A, et al. Intraductal papillary neoplasms of the bile duct. Int J Hepatol 2014;2014:459091

2 Joo I, Lee JM, Yoon JH. Imaging diagnosis of intrahepatic and perihilar cholangiocarcinoma: recent advances and challenges. Radiology 2018;288:7-13.

3 Wan X-S, Xu Y-Y, Qian J-Y, et al. Intraductal papillary neoplasm of the bile duct. World I Gastroenterol 2013;19:8595-604.

4 Lee SS, Kim M-H, Lee SK, et al. Clinicopathologic review of 58 patients with biliary papillomatosis. Cancer 2004;100:783-93.

$5 \mathrm{Lim} \mathrm{JH,} \mathrm{Kim} \mathrm{M-H,} \mathrm{Kim} \mathrm{TK,} \mathrm{et} \mathrm{al.} \mathrm{Papillary} \mathrm{neoplasms} \mathrm{of} \mathrm{the} \mathrm{bile} \mathrm{duct} \mathrm{that} \mathrm{mimic} \mathrm{biliary}$ stone disease. Radiographics 2003;23:447-55.

6 Chung YE, Kim M-J, Park YN, et al. Varying appearances of cholangiocarcinoma: radiologic-pathologic correlation. Radiographics 2009;29:683-700.

7 Luvira V, Pugkhem A, Bhudhisawasdi V, et al. Long-term outcome of surgical resection for intraductal papillary neoplasm of the bile duct. J Gastroenterol Hepatol 2017;32:527-33.

Copyright 2019 BMJ Publishing Group. All rights reserved. For permission to reuse any of this content visit

https://www.bmi.com/company/products-services/rights-and-licensing/permissions/

BMJ Case Report Fellows may re-use this article for personal use and teaching without any further permission.

Become a Fellow of BMJ Case Reports today and you can:

- Submit as many cases as you like

- Enjoy fast sympathetic peer review and rapid publication of accepted articles

- Access all the published articles

Re-use any of the published material for personal use and teaching without further permission

Customer Service

If you have any further queries about your subscription, please contact our customer services team on +44 (0) 2071111105 or via email at support@bmj.com.

Visit casereports.bmj.com for more articles like this and to become a Fellow 